\title{
Film Snowden; antara Paranoia dan Tipuan-Tipuan Klasik Amerika
}

\author{
Zulkifli Makmur \\ Sekolah Tinggi Agama Islam Darud Dakwah wal Irsyad Kota Makassar
}

Zulkifli.makmur@mail.ugm.ac.id

\begin{abstract}
Abstrak
Artikel ini mengulas film Snowden (2016) yang diangkat dari kisah nyata. Film ini dengan menggunakan gagasan Althusserian dapat diduga menciptakan praktek-praktek propaganda Amerika Serikat meskipun tokoh Snowden dan pernyataan-pernyataannya terkait hak perlindungan privasi sendiri telah menyebabkan pemerintah Amerika Serikat pada saat itu sibuk melayangkan klarifikasi atas pernyataan Snowden tersebut. Amerika melalui film tersebut memamerkan berbagai teknologi mutakhir dan kekuatan militer serta industri mata-mata sebagai produk propaganda di hadapan masyarakat dunia.
\end{abstract}

\section{Pendahuluan}

Sejujurnya saya tidak begitu menyenangi film biografi. Meskipun tak banyak mengecap pemikirannya, tak heran, kekaguman saya pada gaya Jacques Derrida membuat apapun terkait Being di dalam teks/fiksi seakan-akan tak lagi dapat dipercaya. Konkretnya, fiksi yang mengeksploitasi tokoh terkenal, oleh penulis/pengarang biografi, berdasarkan cara pandangnya, cenderung memanfaatkan tokoh publik tersebut sebagai alat untuk mengarahkan keberpihakannya, menciptakan frame, ke satu versi kebenaran-tentunya versi kebenaran si pengarang atau ideologi kolektif tertentu. Lalu kenapa saya masih saja menontonnya? Tidak senang bukan berarti menolak. Saya sendiri mengenal lebih dekat almarhum Derrida pun melalui biografi dokumenternya.

Terkhusus Snowden, tidak seperti penonton film alay kebanyakan-bahkan pernah seorang teman menyarankan agar menonton film Snowden walaupun dia sendiri tidak tahu Snowden benarbenar tokoh rill-sejak seanter dibicarakan di tahun 2013, saya mengikuti betul jejak-jejak perjalanan pimpinan Amerika dalam usahanya menangkap si Whistleblower ini, mulai dari pencarian di Hongkong hingga Jerman menawarkan diri sebagai negara suaka Snowden, melindunginya, dan dibuatkan akte kewarganegaraan. Snowden adalah tokoh fenomenal di tahun itu, di tahun yang juga merupakan tahun terakhir lapak baca koran beroperasi di depan kampus I UIN Alauddin. Kepanikan, sebagaimana yang ditampilkan di dalam film Snowden, muncul dimana-mana. Terutama warga Amerika, pasca pengakuan Snowden tersebut, kebencian karena merasa diuntit oleh pemerintahnya sendiri, adalah tindakan tak sopan yang tentu tidak mudah 
dimaafkan meskipun negara berdalih bhwa tindakan tersebut mengatas-namakan pengawasan dan penanggulangan aksi terorisme.

\section{Virus Paranoia}

Semua orang bergidik. Bagaimana tidak? Kehidupan pribadi seseorang dapat sewaktuwaktu tersebar dengan atau tanpa disengaja oleh penguasa pengawasan. Seorang politisi yang dapat mengancam kekuatan dunia dapat dalam sekejap hancur akibat skandal yang sesungguhnya bukan menjadi konsumsi publik. Ayah saya pun, dipengaruhi politik pengawasan tersebut, sempat mengingatkan di tahun-tahun sebelumnya bahwa E-KTP terdapat cip yang dapat diakses di Pentagon US.

Sungguh mengejutkan. Namun bagi saya tidak. Terkejut adalah respon yang diakibatkan oleh hentakan yang berada di luar dari yang biasa dan saya menanggapinya biasa saja. Sebab wacana dan fenomena ini sudah diramalkan jauh hari sebelumnya oleh seorang pengarang dan mungkin jadi seorang peramal. Cenayang itu bernama Dan Brown. Melalui novelnya yang berjudul Digital Fortress di tahun 1997, Dan Brown memperkenalkan kemajuan teknologi NRO pada saat itu. Manusia-manusia modern sudah mengenal teknologi komunikasi yang cukup canggih, begitu pula teknologi NRO yang dapat memindai semua percakapan mereka. Dipertegas lagi di dalam novelnya yang lain berjudul Deception Point digambarkan dengan curangnya pihak presiden petahana menguntit, serta mengabadikan peristiwa skandal lawan politiknya menjelang Pilpres. Quis Custodiet Ipsos Custodes? 'Siapa yang mengawasi para pengawas?' Konsekuensi dari kencangnya arus teknologi sesungguhnya tentu saja berbanding lurus berpuluh kali lipat dengan berkembangnya teknologi pengawasan. Demikianlah adanya. Jadi kenapa mesti khawatir? Mereka menyelidiki pergerakan manusia di pos-pos jaga itu berupaya mengkatalogisir milyaran manusia di muka bumi, termasuk saya, dan anda juga, ke dalam faksi-faksi tertentu. Ya, mirip trilogi fiksi Hunger Games, dan Divergent.

Bagi mereka itu penting. Tanpa memetakan manusia berdasarkan kategori-kategori tertentu hanya akan menimbulkan kekhawatiran munculnya serangan di luar perkiraan yang mereka sebut dengan aksi terorisme, yang pada dasarnya benteng tersebut dibangun bukan untuk melindungi rakyatnya tetapi ini persoalan harga diri kebangsaan. Bagi negara-negara mapan ini, ditembus oleh teroris sama halnya menjatuhkan harga diri negara terutama sistem keamanan dan militernya. Sesungguhnya terlalu naïf jika kita tidak mengkhawatirkan fenomena itu, namun karena hal 
demikian sudah diramalkan atau dalam hal ini saya sudah khawatir dari awal, maka kadar kekhawatiran saya tidak sekuat orang-orang pada saat itu. Dan juga terlalu picik jika membiarkan pengawasan yang menggila tersebut menelanjangi kita sewenang-wenang. Harga diri dan kehormatan seseorang tiba-tiba berada digenggaman sebuah sistem yang apabila sistem tersebut inginkan untuk dilepas maka hari itu juga kehormatan orang tersebut akan tumbang. Mengerikan.

Menonton film Snowden seperti halnya menyaksikan seorang yang mengidap gangguan psikis agatophobia -- suatu gangguan kejiwaan berlebihan terhadap orang-orang asing sehingga ia menutup diri dari dunia luar, sebagaimana sosok yang memerankan Claire dalam film The Best Offer (2013)-- dan berkeinginan mereka yang menontonnya pun merasakan ketakutan yang sama. Sakit jiwa. Melalui film ini, penonton digiring ke dalam peristiwaperistiwa yang dialami Snowden semasa aktif sebagai anggota CIA. Penonton disuguhi tayangan-tayangan yang mengusik rasa kemanusiaan seperti pengeboman teroris dari jarak jauh melalui mata satelit hingga pembeberan dunia domestik dan paling privasi hanya melalui kamera laptop yang dalam keadaan padam. Film ini, melalui gambaran-gambaran tersebut, memberi sugesti kepada penonton agar tertawan dalam penilaian yang antagonistik terhadap US atau CIA, begitu seterusnya hingga film ini ditutup dengan reaksi massa dan Presiden membenahi Undang-Undang Kemerdekaan dari pengawasan. Amerika, kesannya, terbukti adalah negara yang terbuka. Keren, bukan?

\section{Belajar dari Nasehat Kresna}

Film ini ternyata tidak seperti ketakutan saya diawal. Film Snowden sebagaimana kebanyakan box office pada umumnya hanya menceritakan tentang Amerika dan kejayaannya. Propaganda teknologi mutakhir-nya dengan menceritakan sanggup memadamkan seluruh listrik di Jepang, Rusia, dan negara-negara G-8 apabila sewaktu-waktu mereka menolak bersekutu dengan Amerika adalah cara-cara umum yang ditampilkan fiksi Amerika, tentang negaranya yang tercinta. Saya teringat nasehat yang mulia kusir ksatria Arjuna, Kresna. Ia berkata di balik kokoh sebuah cangkang bersembunyi seekor siput yang lembek. Delusi-delusi film action Amerika yang menampilkan teknologi militer yang luar biasa canggihnya, jika dirunut ke belakang, muncul akibat dampak traumatik yang dalam di masa lalu. Teror 9/11, kegagalan menaklukkan Vietnam, catatan-catatan tentang aksi yang berujung fatal pada pejabat publik, serta jauh ke belakang lagi peristiwa Pearl Harbour merupakan fakta-fakta yang tak bisa ditampik negara dengan 50 subnegara ini. Oleh karena itu melalui film-film yang heroik, dan patriotik Amerika berusaha 
menggerus ingatan dunia mengenai kelemahannya melalui delusi cangkang sebagaimana nasehat Kresna di atas.

Coba kita bandingkan dengan film-film era 80'an. Melalui artikelnya, Ariel Heryanto mengungkap hubungan antara tiga film besar yakni Rocky, Missing in Action, Rambo, dan belakangan dia menyebut film The Year Of The Dragon dengan kepemimpinan Presiden Ronald Reagen pada saat itu. Keempat film itu, menurut Ariel, mencirikan gaya kepemimpinan Reagen yang kepala batu dan kontroversi. Film-film ini juga berhubungan dengan gaya politik internasional Reagen, dimana ia menginginkan Amerika selalu menjadi juara dalam kompetisi fisik melawan bangsa apapun di dunia. Hal ini terbukti dengan serangan Amerika di Libya dan Nikaragua. Meskipun dikecam oleh banyak negara bahkan dihina oleh rakyat sendiri, Reagen yang didukung, Ariel menyebutnya, oleh sejumlah tokoh raksasa yang konservatif tampil sebagai "pahlawan" di negerinya dengan mengusung sebuah cita-cita "mengembalikan kejayaan Amerika". $\mathrm{Hmm}$, apa cuma saya yang menganggap dia memiliki kemiripan dengan pemimpin yang sekarang?

Berbeda dengan film-film di satu dekade ini, film bergaya tokoh dengan otot kawat, veteran muda, pertunjukan kejantanan melalui wanita dan pertarungan fisik, dan bermodalkan teknik perang menghadapi masalah saat ini sudah lama ditinggalkan. Teknologi dan multidisiplin pengetahuan menguasai film-film action 10 tahun terakhir ini. Kejahatan didesain jauh lebih kompleks baik itu dalam ideologi, motif, maupun strateginya. Film-film action tampak menyudutkan posisi Amerika, meski diketahui ini hanya penciptaan delusi yang tak lain tujuannya adalah redefinisi nasionalisme dan tentu saja komersial. Karena sesungguhnya film yang menjadi perhatian dunia adalah film dengan tokoh genius yang mampu mengobrak-abrik negara yang pusat Pemerintahannya di Washington D.C itu.

Biasanya dalam film-film ini, kegagalan keamanan negara disebabkan oleh pengkhianatan dari kalangan orang dalam seperti yang dapat dilihat dalam film Vantage Point, Salt, dan White House Down. Suatu pernyataan implisit yang dapat diungkap melalui film-film ini ialah tak ada teknologi termaju di muka bumi yang dapat menembus sistem keamanan Amerika, kecuali dari kalangan mereka sendiri. Wow.

\section{Demokrasi dan Sistem Pengawasan}

Untuk apa memperbaharui sistem keamanan? Hmm, terlalu utopis kiranya jika saya mengatakan sistem keamanan itu tidak penting. Tetapi bukankah jauh lebih penting melahirkan rasa saling percaya ketimbang memperkokoh pagar di halaman rumah? Paranoia memang bukan 
hanya merasuki pikiran pemimpin-pemimpin negara yang menjalani masa perang, atau tengah menghadapi gerakan arus bawah, tetapi juga dialami oleh negara dengan sistem pemerintahan demokrasi yang sangat mapan. Demokrasi merupakan sistem yang sama bahayanya dengan kapitalisme yakni sama-sama menghasilkan pemenang dan orang-orang yang tak pernah mau mengalah. Presiden Jinping, saat diserang oleh kampanye Trump yang mengatakan bahwa salah satu sebab besarnya pengangguran di Amerika adalah warga negara Tiongkok, menyerang balik dengan berkata jangan lupa sistem demokrasi telah melahirkan tokoh-tokoh seperti Mussolini, Hitler, dan yang terakhir adalah Trump.

Di negara-negara berkembang demokrasi masih dipandang sebagai sistem ideal untuk membenahi negerinya, padahal mereka lupa negara-negara Asia dan Afrika memiliki corak aristokrasi yang beragam dan tentunya tidak akan sama dengan Amerika dan Eropa. Tradisi ini mampu menjaga kekhawatiran berlebihan terhadap adanya arus bawah yang kencang, dan rakyat tidak perlu takut dipimpin oleh presidennya sebab keduanya masing-masing menjaga kepercayaan satu dengan yang lain. Hal ini dapat dibuktikan saat penjagaan yang ketat diberlakukan dari radius berkilo-kilo meter untuk mengawal Presiden Obama yang berkunjung di Indonesia, seorang Fidel Castro Presiden Cuba--negara yang diklaim gagal menerapkan demokrasi, ketika diminta mengenakan rompi anti-peluru untuk melindungi dirinya, menolak lalu berkata "kenapa harus takut, saya sudah mengenakan rompi moral." Konsekuensi dari kemapanan demokrasi, yang positivistik dan jauh dari bangunan mitos yang menguatkan fondasi kepercayaan rakyat dan tanggungjawab moril seorang pemimpin ini ialah negara mesti menyediakan sistem pengamanan yang ketat. Amerika telah melakukannya. Sayangnya teknologi pengawasan bukan hanya sekadar mengawal pemimpin dan negara tetapi merupakan gengsi yang mempertaruhkan harga diri suatu bangsa. Melalui fiksi-fiksinya ia seakan-akan membuka dapur sistem pengawasannya tentu saja bukan untuk memberi peluang untuk merusaknya, tetapi membuat mata dunia terkagum-kagum menyaksikan teknologi ultracanggih yang belum satu pun peradaban di dunia ini miliki.

Lalu bagaimana dengan Snowden? Lagi-lagi jika memperhatikan kalimat pembuka di atas, sepertinya saya tertipu lagi.

\section{Referensi}

Makmur, Z., \& Sainuddin, I. H., S. (2020, October 10). Karenang di atas Canon (sebuah Apresiasi). https://doi.org/10.31219/osf.io/k6r94 
Makmur, Z. (2020, October 13). Paradoks Hubungan antara Manusia, Lingkungan, dan Sains dalam Enam Sekuel Film Final Destination (Sebuah Pendekatan Self-Deconstruction). https://doi.org/10.31219/osf.io/eacgs

Makmur, Z. (2020, September 10). Dekonstruksi puisi "The Divine Comedy" karya Dante Alighieri dalam Novel "Inferno" karya Dan Brown. https://doi.org/10.31219/osf.io/cwypx

Makmur, Z. (2020, August 2). Membangun Kesadaran Apokaliptik melalui Sastra di Masa Pandemi. https://doi.org/10.31219/osf.io/utvyk

Makmur, Z., Sainuddin, I. H., S, Arsyam, M., \& HERIANTO, H. (2020, July 4). Paradoxical Relationship between Humans, the Environment, And Science in Final Destination (Movies). https://doi.org/10.31219/osf.io/ukr4q 